Jurnal Basicedu Volume 3 Nomor 3 Tahun 2019 Halaman 850-860

JURNAL BASICEDU

Research \& Learning in Elementary Education

https://jbasic.org/index.php/basicedu

\title{
STRATEGI GURU MENINGKATKAN HASIL BELAJAR MENGGUNAKAN PENDEKATAN SAINTIFIK DI SEKOLAH DASAR
}

\author{
Emiliana Ety Hapsari ${ }^{1}$, M. Syarif Sumantri ${ }^{2}$, I. Made Astra ${ }^{3}$ \\ Universitas Negeri Jakarta, Indonesia \\ Email: emiliana.hapsari@gmail.com ${ }^{1}$
}

\begin{abstract}
Abstrak
Penelitin ini bertujuan untuk mengetahui apakah terdapat pengaruh terhadap hasil belajar IPA kelas IV SD Regina Pacis dalam menggunakan pendekata saintifik, dengan jumlah siswa sebanyak 18 orang siswa. Teknik yang digunakan dalam pengambilan data adalah tes dan non tes. Pembelajaran saintifik yang sudah diterapkan pada siswa kelas IV B SDS Regina Pacis Jakarta mampu meningkatkan hasil belajar IPA yang semula mendapat nilai rata-rata 66.39 pada prasiklus, meningkat menjadi 71.94 pada siklus I dan pada siklus II meningkat menjadi 80.83. Sedangkan untuk aktifitas siswa pun juga meningkat setelah diterapkannya pembelajaran saintif hal ini terbukti dari hasil observasi yang mendapatkan hasil rata-rata 74.1 dan meningkat menjadi 77.78. Sehingga dapat disimpulkan bahwa penerapan pembelajaran saintifik dalam penelitian ini sudah mencapai tujuannya yaitu meningkatkan hasil belajar IPA.
\end{abstract}

Kata kunci: pendekatan saintifik, hasil belajar, sekolah dasar

\begin{abstract}
Scientific learning that has been applied to class IV B students of SDS Regina Pacis Jakarta is able to improve the learning outcomes of science which originally received an average score of 66.39 in pre-cycle, increased to 71.94 in the first cycle and in the second cycle increased to 80.83. As for the activities of students also increased after the implementation of scientific learning this is evident from the results of observations that get an average yield of 74.1 and increased to 77.78. So that it can be concluded that the application of scientific learning in this study has achieved its goal of improving science learning outcomes.

Keyword: scientific approach, learning outcomes, elementary school
\end{abstract}

@ Jurnal Basicedu Prodi PGSD FIP UPTT 2019

Corresponding author:

Address :

Email : : emiliana.hapsari@gmail.com

ISSN 2580-3735 (Media Cetak)

Phone : ISSN 2580-1147 (Media Online) 


\section{PENDAHULUAN}

Pendidikan merupakan salah satu hal penting untuk masa depan suatu bangsa, maka untuk menghasilkan sumber daya manusia yang baik sebagai subjek dalam pembangunan diperlukan modal dari hasil pendidikan itu sendiri. Kurikulum, guru, dan pengajaran atau proses belajar dan mengajar adalah tiga variabel utama yang saling berkaitan dalam strategi pelaksanaan pendidikan di sekolah. Begitu pentingnya sebuah pendidikan maka dicantumkan dalam UndangUndang Bab I pasal 1 ayat 1 No. 20 Tahun 2003 tentang Sistem Pendidikan Nasional dalam penelitian Marzuki (2012) yang berjudul Politik Pendidikan Nasional dalam Bingkai UndangUndang Sistem Pendidikan Nasional menjelaskan bahwa : pendidikan merupakan sebuah usaha secara sadar dan terencana untuk mewujudkan suasana belajar dan proses pembelajaran agar peserta didik secara aktif mengembangkan potensi dirinya untuk memiliki kekuatan spiritual keagamaan, pengendalian diri, kepribadian, kecerdasan, akhlak mulia, serta ketrampilan yang diperlukan dirinya, masyarakat, bangsa dan negara.

Guru sebagai tenaga pendidik dalam proses pembelajaran diharapkan dapat menampilkan keahliannya sebaik mungkin dalam menyampaikan materi pelajaran di depan kelas dan memandang peserta didiknya sebagai manusia yang mempunyai potensi dalam dirinya yang dapat dikembangkan. Sehingga dalam proses pembelajaran tidak hanya sebagai proses pentransferan pengalaman guru terhadap peserta didiknya, akan tetapi merupakan proses untuk menggali dan menemukan sesuatu sebagai pengalaman baru bagi peserta didik.

Fokus utama guru hanyalah ketuntasan dari materi yang harus dipelajari tanpa berorientasi pada cara mengembangkan potensi, kreatifitas, pengetahuan, dan pengalaman belajar siswa. Schuman yang dikutip (Gabel, 1994), seorang Guru IPA seharusnya memiliki beberapa kompetensi dasar yang meliputi: (1) kemampuan Intelektual umum (general intellectual Abbility), (2) pengetahauan atau latar belakang materi ajar (Subject-matter background), (3) Kompetensi pedagogi mengajarkan bidang materi IPA (pedagogical Subject-Matter Competence), (4) Keterampilan dan pengetahuan professional (professional Knowledge and professional skills).

Pada konteks pembelajaran guru seharusnya mampu mengembangkan bakat dan pengetahuan yang dimiliki siswa seperti yang diungkapkan oleh Sanjaya (2008) yang mengemukakan bahwa konteks pembelajaran, dapat diartikan sebagai proses yang sistematis untuk memecahkan persoalan pembelajaran melalui proses perencanaan bahan-bahan pembelajaran beserta aktivitas yang harus sering dilakukan, perencanaan sumber-sumber pembelajaran yang dapat digunakan serta perencanaan evaluasi keberhasilan. Pendekatan yang dapat digunakan dalam desain pembelajaran adalah pendekatan sistem, yang mencakup analisis tentang perencanaan, analisis pengembangan, analisis implementasi dan analisis evaluasi.

Menurut H.W Flowler dalam Trianto (2010) bahwa IPA sebagai pengetahuan yang sistematis dan dirumuskan yang berhubungan dengan gejala-gejala kebendaan dan didasarkan terutama atas pengamatan dan deduksi. Sedangkan Wahyana dalam Trianto (2010) mengatakan bahwa IPA adalah suatu kumpulan pengetahuan yang tersusun secara sistematik, dan dalam penggunaanya secara umum terbatas pada gejalagejala alam.

Selain itu Susanto (2013) juga mengatakan sains atau IPA adalah usaha manusia dalam 
memahami alam semesta melalui pengamatan yang tepat pada sasaran, serta menggunakan prosedur, dan dijelaskan dengan penalaran sehingga mendapatkan suatu kesimpulan.

Dalam kurikulum pendidikan dasar (1994) (dalam tim dosen IPA PGSD UPP3: 40) menjelakan pengertian IPA sebagai hasil kegiatan manusia berupa pengetahuan, pengalaman melalui serangkaian proses ilmiah antara lain penyelidikan, penyusunan, dan pengujian gagasan-gagasan. Pembelajaran IPA di SD dibelajarkan oleh guru dengan menyederhanakan ide dan proses, menyesuaikan dengan minat dan kebutuhan siswa, serta mempertimbangkan kemampuan fisik dan kognitif siswa. Guru berperan sebagai fasilitator pembelajaran, sedangkan siswa aktif mengkonstruksi pengetahuan Yuliariatiningsih (2006).

DeRosa (2010) mengemukakan bahwa Berpikir saintifik (Scientific Thingking) merupakan proses bertanya, mengajukan pertanyaan dan mencari penjelasan. Berpikir sainstifik adalah membantu untuk mengetahui kerangka kerja dari pemikiran scientific dan dapat diajarkan. Salah satu kerangka kerja tersebut dari tiga tahapan model dasar; (1) Descriptive Modeling. Explanatory Modeling, (3) Experimental Modeling.

Dalam buku Yani dan Ruhimat (2018) menjelaskan kata saintifik berasal dari kata sain yang berasal dari Bahasa latin yaitu scientia, dalam Bahasa Inggris menjadi science. Arti sains adalah pengetahuan atau mengetahui ). Lebih lanjut Yani dan Ruhimat (2018) juga menjelaskan bahwa dalam proses pembelajaran saintifik mengacu pada proses belajar ilmiah. Lebih lanjut John Dewey dalam Yani dan Ruhimat (2018) menjelaskan bahwa proses saintifik secara aktif dan ilmiah yaitu menuntut untuk peserta didik mengamati masalah yang ada dilingkungan sekitar, merumuskan hipotesis, mengumpulkan data, dan perumusan kesimpulan.

Dalam hasil penelitian Lederman, Lederman, \& Antink (2013) Sifat dasar literasi ilmiah adalah apa yang mempengaruhi keputusan siswa tentang masalah pribadi dan sosial. Di luar ini, namun para pendidik bekerja untuk mempengaruhi kemampuan siswa untuk melihat sains melalui lensa (sudut pandang) yang lebih holistik. Meneliti sejarah filsafat, dan sosiologi sains itu sendiri memiliki potensi untuk menimbulkan persepsi sains, dalam konteks yang lebih luas yang dapat berdampak pada lensa yang melaluinya siswa melihat dunia.

Hasil penelitian Meyer, Capps, Crawford, \& Ross (2012) mengemukakan; The movement toward inquiry based instruction seeks to reform didactic and lecture-based approaches to science instruction where teachers teach about science rather than engaging students in doing science through involvement in scientific (Meyer, Capps, Crawford, \& Ross, 2012). Pendapat Meyer tentang hasil penelitiannya dapat diartikan; Pergerakan menuju pengajaran berbasis inkuiri bertujuan untuk mereformasi pendekatan didik dan berbasis pada pengajaran sains di mana guru mengajar tentang sains daripada melibatkan siswa dalam melakukan sains melalui keterlibatan dalam keilmuan.

Majid (2014) Pendekatan sainstifik merupakan salah satu pendekatan pembelajaran ilmiah. Penerapan pendekatan sainstifik bertujuan untuk pemahaman kepada peserta didik dalam mengenal, memahami berbagai materi menggunakan pendekatan ilmiah, bahwa informasi bisa berasal dari mana saja, kapan saja, tidak bergantung pada informasi searah dari guru. 
853 Strategi guru meningkatkan hasil belajar menggunakan pendekatan saintifik di sekolah dasar- Emiliana Ety Hapsari, M. Syarif Sumantri, I Mad Astra

Lebih lanjut Daryanto (2014), mengungkapkan bahwa pembelajaran dengan pendekatan saintifik adalah proses pembelajaran yang dirancang sedemikian rupa agar peserta didik secara aktif mengkonstruksi konsep, hukum atau prinsip melalui tahapantahapan mengamati, merumuskan masalah, mengajukan atau merumuskan hipotesis, mengumpulkan data dengan berbagai teknik, menganalisis data, menarik kesimpulan dan mengkomunikasikan konsep, hukum atau prinsip yang ditemukan.

\section{Sedangkan Sani (2014) berpendapat} bahwa "pendekatan saintifik merupakan pendekatan yang berkaitan erat dengan metode saintifik. Metode saintifik (ilmiah) pada umumnya melibatkan kegiatan pengamatan atau observasi yang dibutuhkan untuk perumusan hipotesis atau mengumpulkan data."

Sebagai research awal, melalui proses refleksi diri sebagai guru, observasi sumber belajar dan hasil belajar siswa di Sekolah Dasar Regina Pacis Jakarta khususnya kelas IV yang berjumlah 18 orang di mana terdapat $45 \%$ siswa yang memperoleh hasil belajar rendah atau di bawah ketuntasan belajar minimal yang ditetapkan dapat di analisis bahwa, masalah yang dihadapi dalam pembelajaran IPA khususnya penerapan pembelajaran dengan scientific learning antara lain, siswa yang belum terlibat secara langsung dengan pengalaman belajarnya dan guru yang memerlukan inovasi dalam penggunaan strategi, metode dan media yang menekankan pada proses pengalaman belajar dalam upaya meningkatkan hasil belajar IPA. Sehingga peneliti menganggap perlu dilakukan penelitian tindakan kelas untuk meningkatkan pemahaman scientific learning dalam pembelajaran IPA khususnya materi Gaya, agar siswa lebih merasakan dan memahami pembelajaran IPA serta mencapai tujuan pembelajaran secara optimal.
Berdasarkan fakta yang terjadi pada pembelajaran di kelas IV SD Regina Pacis Jakarta, data yang diperoleh dari 18 siswa sekitar $45 \%$ siswa tidak dapat mencapai kriterian ketuntasan belajar yang ditentukan yaitu dengan nilai 75. Oleh karena itu dibutuhkan sebuah upaya dan usaha secara sadar untuk memperbaiki proses pembelajaran yang ada dengan mengedepankan pendekatan saintifik yang di dalamnya terkandung proses mengamati yang dapat bermanfaat melatih kepedulian siswa terhadap lingkungan sekitar, proses menanya untuk membangkitkan rasa ingin tahu dan mendorong keterampilan berbicara siswa, mengekplorasi untuk mengumpulkan data pengetahuan sebanyak-banyaknya sehingga siswa dapat menalar dengan proses berpikir yang logis dan sistematis atas fakta empiris yang dapat diobservasi untuk memperoleh simpulan berupa pengetahuan yang kemudian dikomunikasikan dengan empati serta saling menghormati satu sama lain. Dengan begitu diharapkan hasil belajar IPA dapat mengalami perubahan dan meningkat dengan baik.

\section{METODE}

Penelitian ini menggunakan penelitian tindakan (action research). Menurut Arikunto (2009) bahwa penelitian tindakan kelas adalah suatu pencermatan terhadap kegiataan pembelajaran dikelas dengan sebuah tindakan. Penelitian ini untuk meningkatkan kualitas dan efesiensi praktik pembelajaran IPA siswa kelas IV dalam meningkatkan hasil belajar siswa di SD Regina Pacis Jakarta.

Penelitian ini dirancang dalam bentuk PTK (penelitian tindakan kelas) dengan model kimmis dan taggart dengan empat langkah kegiatan yaitu diantaranya tahap perencanaan, tahap pelaksanaan tindakan, tahap pengamatan, dan tahap refleksi. Subjek dalam penelitian ini pada kelas IV SD Regina Pacis Jakarta barat yang 
berjumlah 18 orang, yang terdiri dari 10 orang laki-laki dan 8 orang perempuan. Penelitian ini dilakukan selama dua bulan dimulai pada bulan april sampai dengan bulan mei.

Teknik pengumpulan data penelitian ini terdiri dari tes dan non tes. Teknik tes digunakan untuk mengukur tingkat peningkatan hasil belajar siswa disetiap akhir siklus tindakan sebagai akibat dari tindakan yang telah diberikan. Teknik non tes dalam penelitian ini yaitu observasi pembelajaran, catatan lapangan, dokumentasi selama kegiatan pembelajaran, dan angket tentang afektifitas siswa mengenai pembelajaran IPA

\section{HASIL DAN PEMBAHASAN}

Melalui hasil pengamatan yang peneliti lakukan sebelum tindakan diberikan, peneliti melihat bahwa guru dapat menguasai kelas dengan cukup baik saat kegiatan pembelajaran berlangsung. Namun, di sisi lain terlihat bahwa guru mendominasi jalannya pembelajaran. Siswa kurang diajak untuk aktif oleh gurunya dalam kegiatan pembelajaran.

Peroleh informasi menunjukan bahwa guru dalam pelaksanaan pembelajaran Ilmu Pengetahuan Alam melalui kegiatan belajar dengan pendekatan scientific telah dilaksanakan, namun belum efektif dan mendalam pada aspekaspek scientific dalam pembelajaran.

Terkait dengan hasil pengamatan terhadap siswa di kelas tersebut, peneliti juga mengamati bahwa hanya terdapat sedikit siswa yang tertarik untuk aktif memberikan jawaban atas pertanyaan guru secara lisan.

Studi pendahuluan peneliti lanjutkan pada tahap wawancara kepada sejumlah siswa kelas IV B SD Regina Pacis, Jakarta Barat Kesimpulan dari hasil wawancara yang dilakukan peneliti kepada sejumlah siswa adalah pembelajaran khususnya
IPA yang berlangsung memang kurang mengedepankan proses penggalian pengetahuan yang dilakukan oleh siswa sendiri, siswa juga terkadang kurang memahami materi yang dijelaskan oleh guru karena bagi mereka abstrak, guru hanya berpedoman pada buku pelajaran sehingga berakibat sebagian dari siswa memperoleh hasil belajar yang rendah saat tes. Berikut adalah diagram yang menggambarkan kemampuan tes awal (pre test);

\section{Presentase Hasil Tes Kemampuan Awal}

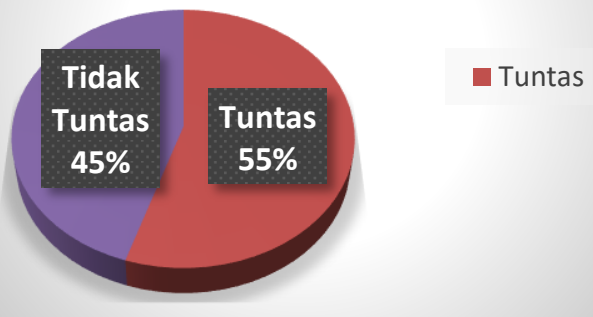

Gambar 1 Presentasi hasil tes kemampuan awal

Siklus satu terdiri dari tiga kali pertemuan yang dilaksanakan dengan pendekatan saintifik dengan tahapan mengamati, menanya, mengumpulkan informasi, mengasosiasikan, dan mengkomunikasikan.

Tabel 1 Hasil evaluasi pengamatan guru siklus I

\begin{tabular}{|c|c|c|c|c|c|}
\hline \multirow{2}{*}{$\begin{array}{c}\text { No } \\
\text {. }\end{array}$} & \multirow{2}{*}{$\begin{array}{l}\text { Fokus } \\
\text { Penilaian }\end{array}$} & \multirow[t]{2}{*}{ Indikator } & \multicolumn{3}{|c|}{$\begin{array}{c}\text { Siklus } \\
\text { Pertemuan }\end{array}$} \\
\hline & & & 1 & 2 & 3 \\
\hline \multirow{4}{*}{ A. } & \multirow{4}{*}{$\begin{array}{l}\text { Membuka } \\
\text { Pelajaran }\end{array}$} & $\begin{array}{l}\text { 1. Penyiapan } \\
\text { ruang, alat, dan } \\
\text { media } \\
\text { pembelajaran. }\end{array}$ & 1 & 1 & 1 \\
\hline & & $\begin{array}{l}\text { 2. Penyiapan } \\
\text { siswa }\end{array}$ & 1 & 1 & 1 \\
\hline & & $\begin{array}{l}\text { 3. Penyampaian } \\
\text { kompetensi dasar }\end{array}$ & 0 & 1 & 1 \\
\hline & & 4. Apersepsi & 1 & 1 & 1 \\
\hline \multirow[b]{2}{*}{ B. } & \multirow{2}{*}{$\begin{array}{l}\text { Penguasaan } \\
\text { Materi; } \\
\text { Penyampaia } \\
\text { n Materi }\end{array}$} & $\begin{array}{l}\text { 5. Penguasaan } \\
\text { materi } \\
\text { pembelajaran }\end{array}$ & 1 & 1 & 1 \\
\hline & & $\begin{array}{l}\text { 6. kesesuaian } \\
\text { materi, prinsip } \\
\text { pengembangan } \\
\text { materi dan contoh } \\
\text { dengan }\end{array}$ & 1 & 1 & 1 \\
\hline
\end{tabular}


855 Strategi guru meningkatkan hasil belajar menggunakan pendekatan saintifik di sekolah dasar- Emiliana Ety Hapsari, M. Syarif Sumantri, I Mad Astra

\begin{tabular}{|c|c|c|c|c|c|}
\hline & & kompetensi dasar & & & \\
\hline & & $\begin{array}{l}\text { 7. Penyampaian } \\
\text { materi sistematis }\end{array}$ & 0 & 0 & 1 \\
\hline \multirow{10}{*}{ C. } & \multirow{10}{*}{$\begin{array}{c}\text { Interaksi } \\
\text { Pembelajara } \\
\text { n dan } \\
\text { skenario } \\
\text { pembelajara } \\
\text { n }\end{array}$} & $\begin{array}{c}\text { 8. Kesesuaian } \\
\text { langkah } \\
\text { pembelajaran } \\
\text { saintifik. } \\
\text { Memberikan } \\
\text { orientasi } \\
\text { pengalaman } \\
\text { belajar dengan } \\
\text { tahap pengamatan }\end{array}$ & 1 & 1 & 1 \\
\hline & & $\begin{array}{c}9 . \\
\text { Mengkondisikan } \\
\text { siswa untuk aktif } \\
\text { bertanya dan } \\
\text { berdiskusi }\end{array}$ & 0 & 0 & 1 \\
\hline & & $\begin{array}{c}10 . \\
\text { Mengorganisasika } \\
\text { n siswa meneliti } \\
\text { untuk } \\
\text { mengumpulkan } \\
\text { informasi }\end{array}$ & 1 & 1 & 1 \\
\hline & & $\begin{array}{l}\text { 11. Membantu } \\
\text { siswa untuk } \\
\text { mengolah serta } \\
\text { menganalisa } \\
\text { informasi yang } \\
\text { telah didapat }\end{array}$ & 0 & 0 & 1 \\
\hline & & $\begin{array}{l}\text { 12. Membimbing } \\
\text { siswa untuk } \\
\text { melakukan } \\
\text { presentasi dengan } \\
\text { tujuan penyajian } \\
\text { informasi }\end{array}$ & 0 & 1 & 1 \\
\hline & & $\begin{array}{c}\text { 13. Keefektifan } \\
\text { pengolahan kelas }\end{array}$ & 0 & 0 & 1 \\
\hline & & $\begin{array}{l}\text { 14. Ketepatan } \\
\text { teknik bertanya } \\
\text { dan menanggapi }\end{array}$ & 0 & 0 & 1 \\
\hline & & $\begin{array}{c}\text { 15. Kecukupan } \\
\text { penggunaan waktu }\end{array}$ & 0 & 1 & 1 \\
\hline & & $\begin{array}{l}\text { 16. Kesesuaian } \\
\text { penggunaan } \\
\text { pendekatan } \\
\text { pembelajaran } \\
\text { dengan materi }\end{array}$ & 1 & 1 & 1 \\
\hline & & $\begin{array}{l}\text { 17. Kecakapan } \\
\text { menggunakan } \\
\text { sumber belajar } \\
\text { dan media }\end{array}$ & 0 & 1 & 1 \\
\hline \multirow{4}{*}{ D. } & \multirow{4}{*}{$\begin{array}{l}\text { Penggunaan } \\
\text { Bahasa; } \\
\text { Penampilan } \\
\text { gerak; } \\
\text { alokasi } \\
\text { waktu }\end{array}$} & $\begin{array}{l}\text { 18. Volume suara, } \\
\text { kejelasan vokal, } \\
\text { kelancaran bicara } \\
\text { dan variasi } \\
\text { intonasi. }\end{array}$ & 0 & 0 & 0 \\
\hline & & $\begin{array}{c}\text { 19. Ketepatan } \\
\text { penggunaan } \\
\text { bahasa dan isyarat }\end{array}$ & 0 & 1 & 1 \\
\hline & & $\begin{array}{c}\text { 20. Keefektifan } \\
\text { dan keluwesan } \\
\text { gerak }\end{array}$ & 1 & 1 & 1 \\
\hline & & $\begin{array}{l}\text { 21. Kepercayaan } \\
\text { diri, interaksi }\end{array}$ & 0 & 1 & 0 \\
\hline
\end{tabular}

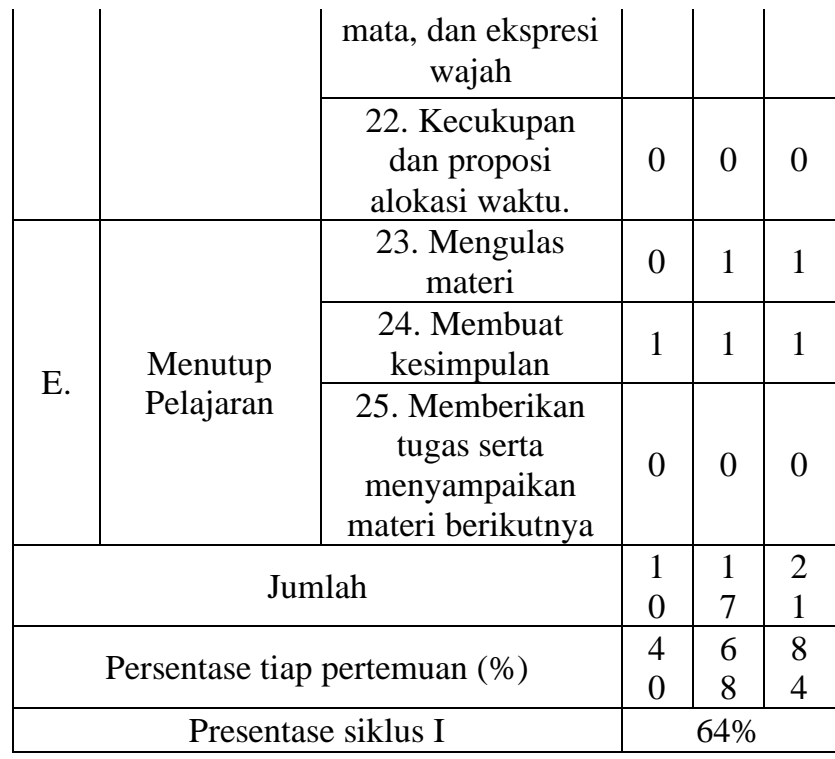

Dari data yang terpaparkan dalam tabel di atas mengenai evaluasi kegiatan guru pada siklus 1 dapat dilihat hampir semua komponen atau point yang menjadi landasan guru mengajar dapat terpenuhi dengan baik. Namun ada point-point yang belum dapat dipenuhi oleh guru selama proses pembelajaran siklus 1 ini antara lain kepercayaan diri, penggunaan volume suara, kecukupan waktu dan pemberian tugas untuk siswa agar siswa mempelajari materi berikutnya.

Setelah tindakan siklus I dilaksanakan maka pada tahap refleksi. Refleksi ini diperoleh berdasarkan hasil observasi melalui pengamatan aktifitas siswa dan guru, catatan lapangan, serta hasil dokumentasi dari pertemuan pertama hingga pertemuan ketiga yang dianalisis.

Peneliti dan observer menyimpulkan proses pembelajaran yang dilaksanakan belum maksimal walaupun ada perbaikan pada media, pendekatan, referensi bahan ajar, dan penilaian

Hasil belajar yang ingin ditingkatkan pada siklus ke II ini antara lain mencakup hasil 
belajar kognitif, afektif, dan psikomotorik. Pada tahap pelaksanaan, tindakan yang dilaksanakan sesuai dengan perencanaan yang telah disiapkan sebelumnya. Siklus II terdiri dari tiga pertemuan.

Kegiatan pembelajaran menggunakan pendekatan saintifik dengan memperhatikan tujuan pembelajaran yaitu adanya peningkatan hasil belajar IPA sudah sangatlah bervariatif, seperti belajar sambil bermain, belajar dalam kelompok, melakukan pengamatan, bernyanyi, menonton video pembelajaran, membuat sebuah keterampilan dengan tujuan pembuktian gaya dapat mengubah bentuk benda, dan belajar menggunakan teknologi digital dan akses jaringan internet untuk menambah pemerolehan informasi serta peningkatan budaya literasi dengan membaca buku terkait materi di dalam perpustakaan.

Dalam pembagian kelompok guru juga sudah melakukan pembagian kelompok dengan baik, adapun pembagian kelompok yang dilakukan dengan memperhatikan kemampuan akademik siswa, sehingga siswa yang memiliki kemampuan akademik unggul dapat membantu siswa yang kurang untuk memahami materi secara bersama-sama. Pada siklus II peneliti dan observer juga menilai adanya perbaikan pada proses pendekatan saintifik dimana pada tahap mengamati siswa sudah lebih fokus, guru juga lebih mengarahkan proses pengamatan yang benar dan memanfaatkan indra siswa seperti mengamati dengan melihat, meraba, dan mendengar. Berikut adalah hasil penilaian observer berdasarkan tindakan observasi pada siklus ke dua
Tabel 2 Observasi aktivitas guru pelaksanaan pembelajaran siklus II.

\begin{tabular}{|c|c|c|c|c|c|}
\hline \multirow{2}{*}{$\begin{array}{c}\text { No } \\
\cdot\end{array}$} & \multirow{2}{*}{$\begin{array}{c}\text { Fokus } \\
\text { Penilaian }\end{array}$} & \multirow{2}{*}{ Indikator } & \multicolumn{3}{|c|}{$\begin{array}{c}\text { Siklus } \\
\text { Pertemuan }\end{array}$} \\
\hline & & & 1 & 2 & 3 \\
\hline \multirow{4}{*}{ A. } & \multirow{4}{*}{$\begin{array}{c}\text { Membuka } \\
\text { Pelajaran }\end{array}$} & $\begin{array}{l}\text { 1. Penyiapan ruang, } \\
\text { alat, dan media } \\
\text { pembelajaran. }\end{array}$ & 1 & 1 & 1 \\
\hline & & 2. Penyiapan siswa & 1 & 1 & 1 \\
\hline & & $\begin{array}{c}\text { 3. Penyampaian } \\
\text { kompetensi dasar }\end{array}$ & 1 & 1 & 1 \\
\hline & & 4. Apersepsi & 1 & 1 & 1 \\
\hline \multirow{3}{*}{ B. } & \multirow{3}{*}{$\begin{array}{l}\text { Penguasaan } \\
\text { Materi; } \\
\text { Penyampaia } \\
\text { n Materi }\end{array}$} & $\begin{array}{l}\text { 5. Penguasaan materi } \\
\text { pembelajaran }\end{array}$ & 1 & 1 & 1 \\
\hline & & $\begin{array}{l}\text { 6. kesesuaian materi, } \\
\text { prinsip } \\
\text { pengembangan materi } \\
\text { dan contoh dengan } \\
\text { kompetensi dasar }\end{array}$ & 1 & 1 & 1 \\
\hline & & $\begin{array}{l}\text { 7. Penyampaian } \\
\text { materi sistematis }\end{array}$ & 1 & 1 & 1 \\
\hline \multirow{10}{*}{ C. } & \multirow{10}{*}{$\begin{array}{c}\text { Interaksi } \\
\text { Pembelajara } \\
\text { n dan } \\
\text { skenario } \\
\text { pembelajara } \\
\text { n }\end{array}$} & $\begin{array}{l}\text { 8.Kesesuaian langkah } \\
\text { pembelajaran } \\
\text { saintifik. } \\
\text { Memberikan orientasi } \\
\text { pengalaman belajar } \\
\text { dengan tahap } \\
\text { pengamatan } \\
\end{array}$ & 1 & 1 & 1 \\
\hline & & $\begin{array}{l}\text { 9. Mengkondisikan } \\
\text { siswa untuk aktif } \\
\text { bertanya dan } \\
\text { berdiskusi }\end{array}$ & 1 & 1 & 1 \\
\hline & & $\begin{array}{c}10 . \\
\text { Mengorganisasikan } \\
\text { siswa meneliti untuk } \\
\text { mengumpulkan } \\
\text { informasi } \\
\end{array}$ & 1 & 1 & 1 \\
\hline & & $\begin{array}{l}\text { 11. Membantu siswa } \\
\text { untuk mengolah serta } \\
\text { menganalisa } \\
\text { informasi yang telah } \\
\text { didapat }\end{array}$ & 1 & 1 & 1 \\
\hline & & $\begin{array}{l}\text { 12. Membimbing } \\
\text { siswa untuk } \\
\text { melakukan presentasi } \\
\text { dengan tujuan } \\
\text { penyajian informasi }\end{array}$ & 1 & 1 & 1 \\
\hline & & $\begin{array}{c}\text { 13. Keefektifan } \\
\text { pengolahan kelas }\end{array}$ & 1 & 1 & 1 \\
\hline & & $\begin{array}{l}\text { 14. Ketepatan teknik } \\
\text { bertanya dan } \\
\text { menanggapi }\end{array}$ & 1 & 1 & 1 \\
\hline & & $\begin{array}{c}\text { 15. Kecukupan } \\
\text { penggunaan waktu }\end{array}$ & 1 & 1 & 1 \\
\hline & & $\begin{array}{c}\text { 16. Kesesuaian } \\
\text { penggunaan } \\
\text { pendekatan } \\
\text { pembelajaran dengan } \\
\text { materi } \\
\end{array}$ & 1 & 1 & 1 \\
\hline & & $\begin{array}{c}\text { 17. Kecakapan } \\
\text { menggunakan sumber } \\
\text { belajar dan media }\end{array}$ & 1 & 1 & 1 \\
\hline \multirow{3}{*}{ D. } & \multirow{3}{*}{$\begin{array}{l}\text { Penggunaan } \\
\text { Bahasa; } \\
\text { Penampilan } \\
\text { gerak; } \\
\text { alokasi } \\
\text { waktu }\end{array}$} & $\begin{array}{l}\text { 18. Volume suara, } \\
\text { kejelasan vokal, } \\
\text { kelancaran bicara dan } \\
\text { variasi intonasi. }\end{array}$ & 1 & 1 & 1 \\
\hline & & $\begin{array}{l}\text { 19. Ketepatan } \\
\text { penggunaan bahasa } \\
\text { dan isyarat }\end{array}$ & 1 & 1 & 1 \\
\hline & & $\begin{array}{l}\text { 20. Keefektifan dan } \\
\text { keluwesan gerak }\end{array}$ & 1 & 1 & 1 \\
\hline
\end{tabular}


857 Strategi guru meningkatkan hasil belajar menggunakan pendekatan saintifik di sekolah dasar- Emiliana Ety Hapsari, M. Syarif Sumantri, I Mad Astra

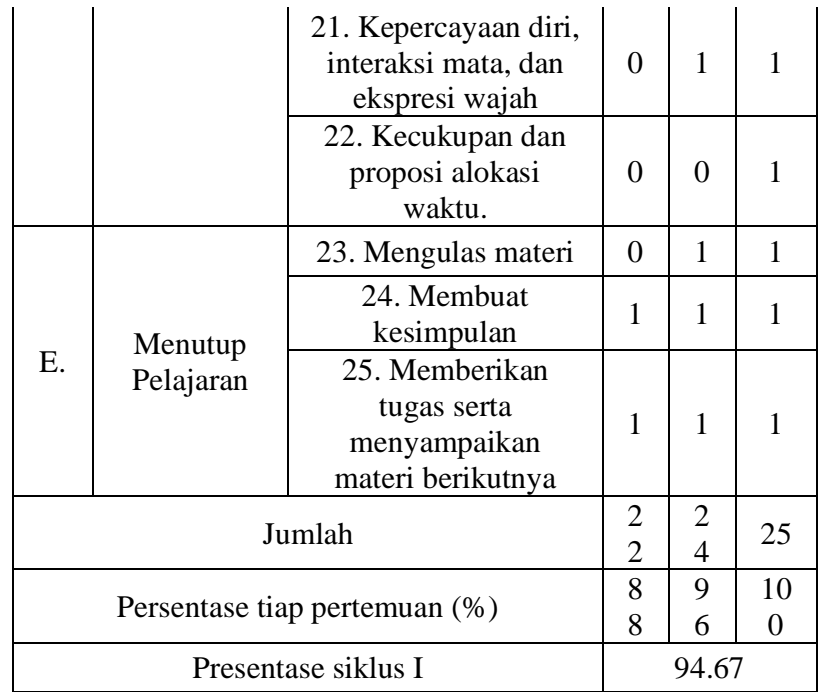

Setelah tindakan siklus II dilaksanakan

maka pada tahap refleksi ini peneliti dan observer kembali melakukan sejumlah diskusi untuk membahas kekuatan dan perbaikanperbaikan

Peneliti dan observer menyimpulkan siswa dalam mengalami proses pembelajaran yang dilaksanakan pada siklus II sudah mengalami perbaikan dibandingkan sebelumnya pada siklus I. Perbaikan tersebut digambarkan pada tabel di bawah ini;

Tabel 3 Perbaikan Siswa dari Siklus I ke siklus II

\begin{tabular}{|c|c|c|c|c|}
\hline No & $\begin{array}{c}\text { Kompo } \\
\text { nen }\end{array}$ & Siklus I & Siklus II & Keterangan \\
\hline $\begin{array}{l}1 \\
.\end{array}$ & $\begin{array}{c}\text { Observ } \\
\text { asi } \\
\text { atau } \\
\text { penga } \\
\text { matan }\end{array}$ & $\begin{array}{l}\text { Belum } \\
\text { teliti }\end{array}$ & $\begin{array}{l}\text { Sudah } \\
\text { teliti }\end{array}$ & $\begin{array}{c}\text { Ada } \\
\text { perbaikan }\end{array}$ \\
\hline 2 & $\begin{array}{c}\text { Bertan } \\
\text { ya }\end{array}$ & $\begin{array}{l}\text { Belum } \\
\text { kritis, } \\
\text { belum } \\
\text { antusias } \\
\text { dan malu } \\
\text { - malu }\end{array}$ & $\begin{array}{c}\text { Mulai } \\
\text { kritis, } \\
\text { mulai } \\
\text { antusias } \\
\text { dan berani }\end{array}$ & $\begin{array}{c}\text { Ada } \\
\text { perbaikan }\end{array}$ \\
\hline 3 & $\begin{array}{l}\text { Menal } \\
\text { ar }\end{array}$ & $\begin{array}{l}\text { Menjawa } \\
\text { b } \\
\text { pertanyaa } \\
\text { n masih } \\
\text { teks book }\end{array}$ & $\begin{array}{l}\text { Sudah } \\
\text { mulai } \\
\text { mampu } \\
\text { menalar }\end{array}$ & $\begin{array}{c}\text { Ada } \\
\text { perbaikan }\end{array}$ \\
\hline $\begin{array}{l}4 \\
.\end{array}$ & $\begin{array}{l}\text { Presen } \\
\text { tasi }\end{array}$ & $\begin{array}{l}\text { Belum } \\
\text { tertarik, } \\
\text { belum } \\
\text { serius, } \\
\text { belum } \\
\text { memperh } \\
\text { atikan }\end{array}$ & $\begin{array}{l}\text { Mulai } \\
\text { tertarik, } \\
\text { mulai } \\
\text { serius dan } \\
\text { efektif }\end{array}$ & $\begin{array}{c}\text { Ada } \\
\text { perbaikan }\end{array}$ \\
\hline
\end{tabular}

Sedangkan untuk hasil tes, berdasarkan hasil refleksi dengan memperhatikan perbandingan hasil siklus I dengan siklus II mengenai proses pembelajaran untuk meningkatkan hasil belajar IPA melalui pendekatan saintifik disimpulkan sudah baik dan mengalami peningkatan. Hal ini dibuktikan dari grafik pemerolehan nilai tes di bawah ini;

\section{Perbandingan Hasil Tes Siklus | \& Siklus ||}

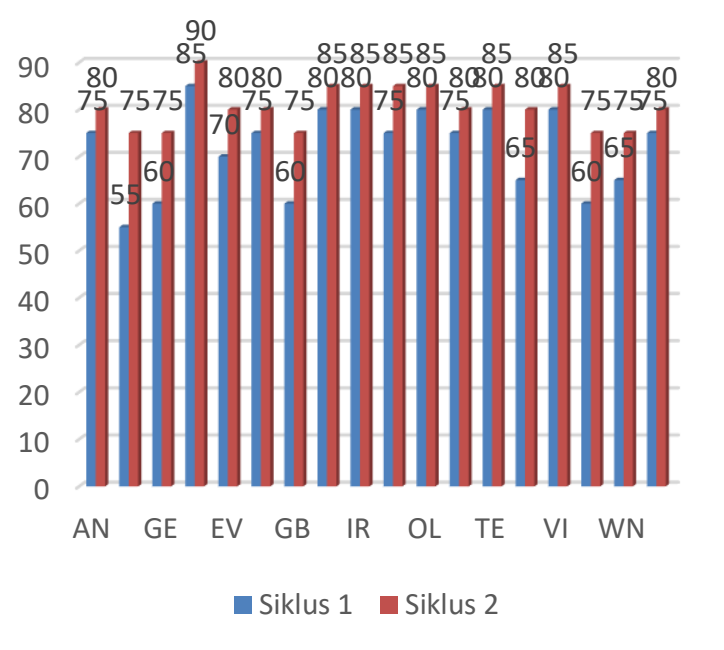

Gambar 2 Perbandingan hasil tes siklus 1 dan siklus

Sebagai bahan refleksi lainnya guru juga meminta siswa memberikan tanggapan mengenai pembelajaran yang telah berlangsung selama siklus I dan siklus II. Berikut gambar ungkapan perasaan siswa yang digambarkan dalam tabel di bawah ini.

Tabel 4 tanggapan siswa

\begin{tabular}{|c|c|c|}
\hline Tanggapan & Siklus I & Siklus II \\
\hline Sangat menyenangkan & $56 \%$ & $83 \%$ \\
\hline Cukup menyenangkan & $33 \%$ & $17 \%$ \\
\hline Tidak menyenangkan & $11 \%$ & - \\
\hline Berdasarkan & pengamatan & yang
\end{tabular}

dilakukan oleh observer selama proses pembelajaran, observer menilai pelaksanaan pembelajaran saintifik dalam pembelajaran dengan lembar pengalaman belajar scientific 
learning. Penilaian yang diberikan oleh observer dapat dilihat pada tabel berikut :

berikut :

\section{Tabel 5 Penilaian pembelajaran saintifik}

\begin{tabular}{|c|c|c|}
\hline $\begin{array}{c}\text { Pengalaman belajar } \\
\text { scientifik }\end{array}$ & $\begin{array}{c}\text { Nila } \\
\text { i }\end{array}$ & Keterangan \\
\hline Mengamati & 90 & $\begin{array}{c}\text { Pada kegiatan mengamati } \\
\text { sudah banyak siswa yang } \\
\text { aktif dan serius dalam } \\
\text { pengamatan. }\end{array}$ \\
\hline Menanya & 85 & $\begin{array}{c}\text { Pada kegiatan menanya } \\
\text { siswa sudah cukup aktif } \\
\text { untuk bertanya ataupun } \\
\text { menjawab pertanyaan } \\
\text { (diskusi) }\end{array}$ \\
\hline $\begin{array}{c}\text { Mengumpulkan } \\
\text { informasi }\end{array}$ & 90 & $\begin{array}{c}\text { Pada kegiatan } \\
\text { mengumpulkan informasi } \\
\text { siswa yang terlihat aktif dan } \\
\text { terstruktur dengan baik. }\end{array}$ \\
\hline $\begin{array}{c}\text { Mengolah informasi } \\
\text { (mengasosiasikan) }\end{array}$ & 95 & $\begin{array}{c}\text { Pada kegiatan mengolah } \\
\text { informasi, siswa sudah } \\
\text { mampu menganalisis } \\
\text { informasi yang di dapat dan } \\
\text { siswa terlihat aktif } \\
\text { berpartisipasi. }\end{array}$ \\
\hline Mengkomunikasika \\
$\mathrm{n}$
\end{tabular}

Penilaian yang diberikan observer menunjukan adanya peningkatan terhadap siklus II dibandingkan dengan siklus I.

Berdasarkan penelitian tindakan yang diterapkan pada siswa kelas IV B SD Regina Pacis Jakarta dengan menggunakan pendekatan scientific maka hasilnya dapat dinyatakan mengalami peningkatan hasil belajar. Peningkatan ini terjadi karena proses refleksi dari satu siklus ke siklus berikutnya.

Terkait hasil observasi pra tindakan maka didapat bahwa pembelajaran IPA yang selama ini dilakukan menghasilkan hasil belajar yang rendah dan kurang mengedepankan keterampilan pembelajaran saintifik. Siswa tidak mengalami proses pengamatan, pencarian informasi, menanya, mengolah informasi, dan saling mengkomunikasikan. Data yang menyatakan bahwa masih banyak siswa yang belum mampu memenuhi kriteria ketuntasa minimal pada hasil belajarnya. Sedangkan setelah dilakukannya siklus I dan siklus II dengan menggunakan pendekatan belajar saintific maka tampaklah peningkatan hasil belajar IPA.

Dapat disimpulkan pada penilaian kognitif yang diperoleh melalui instrument tes, pada pra siklus memperoleh nilai rata-rata kelas sebanyak 66.39, dan pada siklus I setelah dilaksanakannya pembelajaran materi gaya dengan pendekatan saintifik meningkat menjadi 71.94 dan pada siklus II juga mengalami peningkatan menjadi 80.83 . Peningkatan ini terjadi setelah dilaksanakannya proses pembelajaran dengan pendekatan saintifik.

Sedangkan pada aspek afektif penilaian didapat dengan pengamatan melalui angket dengan kriteria yang sudah ditetapkan. Pada aspek kriteria minat, indikatornya adalah ketertarikan untuk mencari informasi, belajar, berdiskusi dan adanya perhatian pada guru. Aspek yang terakhir pada afektif adalah konsep diri dengan indicator motivasi dan lapang dada. Data yang diperoleh melalui penilaian afektif pada siklus I sebesar $52.45 \%$ dan meningkat pada siklus II menjadi $85.71 \%$.

Sedangkan penilaian psikomotorik dengan aspek penilaian pada perencanaan kerja dengan indicator memuat tujuan yang jelas, membaca prosedur kerja, mempersiapkan alat dan bahan yang dibutuhkan dengan lengkap, dan mengecek alat dan bahan. Aspek pelaksanaan dengan indicator menggunakan alat dan bahan sesuai dengan tujuan percobaan dan bersikap kerja sama antar kelompok, dan aspek kriteria dengan ketentuan sistimatika penulisan benar memuat tujuan dari percobaan dan menuliskan langkahlangkah kerja dengan runtut. Pada penilaian aspek psikootorik ini juga mengalami peningkatan dari 
siklus satu mendapat nilai rata-rata sebanyak $72.84 \%$ dan pada siklus ke II meningkat menjadi $91.36 \%$.

Sehingga dapat disimpulkan bahwa penilaian hasil belajar siswa mengenai IPA materi gaya pada siswa kelas IV SD Regina Pacis Jakarta mengalami peningkatan setelah dilaksanakannya proses pelaksanaan pembelajaran dengan pendekatan saintifik.

Berdasarkan hasil penelitian tersebut ditemukan peningkatan pada aktivitas yang dilakukan oleh guru maupun siswa pada setiap pertemuannya disetiap siklusnya, ini terjadi karena adanya refleksi yang digunakan sebagai bahan perbaikan. Seperti yang terjadi pada siklus I guru kurang bersemangat, kurang interaktif dan kurang memotivasi siswa, maka dari hasil refleksi tersebut guru jadikan sebagai bahan perbaikan di siklus II sehingga pada siklus II guru mampu membawakan dirinya secara lebih lagi. Sedangkan pada siswa juga terjadi peningkatan dari siklus I ke siklus II. Jika pada siklus I masih terdapat siswa yang tidak bersemangat, kurangnya pemahaman, pasif dan peningkatan hasil belajar yang belum maksimal, maka pada siklus II setelah siswa mengalami perubahan dengan arah yang positif terbukti dengan meningkatnya aktivitas siswa di siklus II. Pada siklus II siswa lebih aktif dalam mengamati, melakukan percobaan, menggumpulkan informasi, mengkomunikasikan dengan menunjukan karakter yang bertanggung jawab, disiplin, memiliki rasa ingin tahu yang tinggi, dan berani. Penerapan pendekatan saintifik ini juga melatih siswa untuk meningkatkan sosialnya dengan sesama teman melalui kegiatan kelompok, saling membantu antar anggota kelompok sehingga terjadi peningkatan pengetahuan yang diperoleh siswa.

Peningkatan ini dapat terjadi juga dikarenakan adanya kerjasama yang baik antara peneliti, siswa, dan observer dalam melaksanakan penelitian tindakan kelas ini, karena pada prinsipnya penelitian tindakan kelas ini merupakan penelitian kolaboratif yang melibatkan rekan sejawat untuk memperbaiki keadaan ataupun memecahkan suatu masalah yang ditemukan di kelas. Selama peneliti mengerti arah dan tujuan penelitian, mengerti hal-hal apa saja yang harus diperbaiki, mengetahui dan memahami tahapan pendekatan saintifik, maka penelitian masih dapat berjalan dengan baik. Hal ini ditandai dengan tercapainya tujuan penelitian yaitu terjadinya peningkatan hasil belajar IPA.

\section{SIMPULAN}

Berdasarkan uraian di atas dapat disimpulkan bahwa strategi guru dalam meningkatkan hasil belajar dengan pendekatan saintifik pada pelajaran IPA Sekolah Dasar Jakarta.bahwa pembelajaran dengan pendekatan saintifik dapat meningkatkan hasil belajar siswa serta dapat meningkatkan pemahaman-pemahaman siswa terkait materi karena dengan pembelajaran saintifik siswa diajak untuk mengkonstruk pengetahuannya melalui proses-proses ilmiah. Pembelajaran saintifik yang sudah diterapkan pada siswa kelas IV B SDS Regina Pacis Jakarta mampu meningkatkan hasil belajar IPA yang semula mendapat nilai rata-rata 66.39 pada prasiklus, meningkat menjadi 71.94 pada siklus I dan pada siklus II meningkat menjadi 80.83. Sedangkan untuk aktifitas siswa pun juga meningkat setelah diterapkannya pembelajaran saintif hal ini terbukti dari hasil observasi yang mendapatkan hasil rata-rata 74.1 dan meningkat menjadi 77.78. Sehingga dapat disimpulkan penerapan pembelajaran saintifik 
860 Strategi guru meningkatkan hasil belajar menggunakan pendekatan saintifik di sekolah dasar- Emiliana Ety Hapsari, M. Syarif Sumantri, I Mad Astra

dalam penelitian ini sudah mencapai tujuannya yaitu meningkatkan hasil belajar IPA.

\section{DAFTAR PUSTAKA}

Arikunto, S. (2009) Prosedur penelitian suatu pendekatan praktik. Edisi Revisi 6. Jakarta: Rineka Cipta.

Marzuki. (2012). Politik Pendidikan Nasional dalam Bingkai Undang-undang Sistem Pendidikan Nasional. Jurnal Penelitian Humaniora, 17(2), 16-38.

DeRosa, J. A. and D. (2010). Teaching Children Science, A Discovery Approach. Seventh Edition. In Pearson International Edition.

Gabel, D. (1994). Handbook Of Research On Science Teaching and Learning. New York: Macmillan.

Lederman, N. G., Lederman, J. S., \& Antink, A. (2013). Nature of Science and Scientific Inquiry as Contexts for the Learning of Science and Achievement of Scientific Literacy Nature of Science and Scientific Inquiry as Contexts for the Learning of Science and Achievement of Scientific Literacy. International Journal of Education in Mathematics Science and Technology, 1(3), 138-147.

https://doi.org/10.18404/ijemst.19784.

Majid, A. (2014). Pembelajaran Tematik Terpadu. Bandung: PT Remaja Rosdakarya.Prestasi Sains dan Matematika Indonesia Menurun Artikel ini telah tayang di Kompas.com dengan

judul"PrestasiSainsdanMatematikaIndonesiaM enurun",https://edukasi.kompas.com/read/2012 /12/14/09005434/Prestasi.Sains.dan.Matemati ka .Indonesia.Menurun.

Marzuki. (2012). Politik Pendidikan Nasional dalam Bingkai Undang-undang Sistem Pendidikan Nasional. Jurnal Penelitian Humaniora, 17(2), 16-38.

Meyer, X. S., Capps, D. K., Crawford, B. A., \& Ross, R. (2012). Using Inquiry and Tenets of Multicultural Education to Engage Latino English-Language Learning Students in
Learning About Geology and the Nature of Science. Journal of Geoscience Education, 60(3), 212-219. https://doi.org/10.5408/10213.1.

Ruhimat, A. Y. \& M. (2018). TEORI DAN IMPLEMENTASI PEMBELAJARAN SAINTIFIK KURIKULUM 2013. Bandung: PT Refika Aditama.

Sani, R. A. (2014a). Pembelajaran Sainstifik Untuk Implementasi Kurikulum 2013. Jakarta: Bumi Aksara.

Susanto, A. (2013). Teori Belajar dan Pembelajaran di Sekolah Dasar. Jakarta: Kencana Prenada Media Group.

Trianto. (2010). Model Pembelajaran Terpadu: konsep, strategi, dan impleentasinya dalam kurikulum KTSP. Jakarta: Bumi Aksara.

Yuliariatiningsih, M. S. (2006). Media komik pada pelajaran ipa untuk meningkatkan. (20). 